e-ISSN 2540-9840 p-ISSN 1412-3770

Accredited by Ministry of Research, Technology

and Higher Education No: 28/E/KPT/2019
Jurnal Ilmiah Sains, Oktober 2021, 21(2):137-144

DOI: https://doi.org/10.35799/jis.v21i2.33861

Available online at https://ejournal.unsrat.ac.id/index.php/jis

\title{
Karakteristik Fisik, Total Padatan dan Hedonik Velva Nangka dengan Penambahan Gum Arab Sebagai Penstabil
}

\author{
Siti Susanti ${ }^{1)}$, V. Priyo Bintoro ${ }^{1)}$, Danur Restu Amanullah ${ }^{1)}$ \\ 1)Program Studi Teknologi Pangan, Departemen Pertanian, Fakultas Peternakan dan Pertanian, \\ Universitas Diponegoro, Semarang, Indonesia \\ sitisusanti@live.undip.ac.id
}

\begin{abstract}
ABSTRAK
Velva nangka (VN) merupakan ekstensifikasi usaha pengolahan nangka sebagai hidangan pencuci mulut beku yang disukai. VN yang berkualitas menggunakan bahan penstabil yaitu kombinasi Carboxyl Methil Celullose (CMC) dan Gum Arab (GA). Penelitian ini bertujuan untuk mengetahui pengaruh penambahan GA sebagai bahan penstabil tunggal terhadap karakteristik fisik (overrun dan waktu pelelehan), total padatan dan hedonik VN. GA dengan variasi konsentrasi $0 ; 0,25 ; 0,5$; 0,75 ; dan $1 \%$ terhadap total adonan digunakan sebagai penstabil pada pembuatan VN. Penambahan GA berpengaruh nyata pada karakteristik fisik dan total padatan serta hedonik tekstur namun tidak mempengaruhi rasa dan aroma VN. VN dengan penstabil GA $1 \%$ mempunyai overrun terendah $(P<0,05)$ sedangkan GA $>0,25-1 \%$ menghasilkan $\mathrm{VN}$ dengan waktu pelelehan lebih lama dan total padatan lebih tinggi $(P<0,05)$. Penambahan GA $>0,5-1 \%$ menghasilkan $\mathrm{VN}$ dengan tekstur yang makin disukai $(P<0,05)$. Penambahan penstabil GA lebih dari $0,25 \%$ dalam adonan mampu menghasilkan VN berkualitas baik ditinjau dari karakteristik fisik dan total padatan dengan tekstur yang disukai.
\end{abstract}

Kata kunci: Gum arab; nangka; penstabil; velva

\section{Characteristic of Physicals, Total Solids and Hedonik of Jackfruit Velva with Addition of Arabic Gum as Stabilizer}

\begin{abstract}
Jackfruit velva (JV) is a business extensification of the jackfruit processing as a preferred frozen dessert. Good quality JV used a stabilizer such as combination of Carboxyl Methyl Cellullose (CMC) and Arabic Gum (AG). This study aimed to get more insight the effect of AG addition as a single stabilizer to the physical characteristics (overrun and melting time), total solids and hedonic $\mathrm{JV}$. AG in various concentration of $0 ; 0.25 ; 0.5 ; 0.75$; and $1 \%$ of the total dough was used as a stabilizer in the JV manufacture. The addition of AG significantly affected the physical characteristic, total solids and texture hedonic without any effect on the flavor and aroma of JV. JV with $1 \%$ AG stabilizer had the lowest overrun $(\mathrm{P}<0.05)$ while $>0.25-1 \%$ AG resulted in JV with longer melting time and higher total solids $(\mathrm{P}<0.05)$. The addition of $>0.5-1 \%$ AG resulted JV more favorable texture $(\mathrm{P}<0.05)$. The addition of more than $0.25 \%$ AG stabilizer in the dough was able to produce good quality JV in the aspects of physical characteristics and total solids with a preferred texture.
\end{abstract}

Keywords: Arabic gum; jackfruit; stabilizer; velva

(Article History: Received 21-04-2021; Accepted 27-09-2021; Published 01-10-2021)

\section{PENDAHULUAN}

Velva merupakan frozen dessert yang berasal dari puree buah yang memiliki tekstur mirip dengan es krim.Velva kaya akan serat alami dan vitamin serta memiliki kandungan lemak yang rendah karena tidak menggunakan lemak tambahan seperti es krim (Lestari et al., 2017). Produk ini sangat cocok dikonsumsi oleh kelompok vegetarian maupun orangorang yang sedang menjalani diet rendah lemak (Maria dan Zubaidah, 2014). Komponen utama dalam pembuatan velva adalah buah, pemanis, dan bahan penstabil. 
Salah satu buah yang dapat digunakan sebagai bahan utama velva adalah nangka (Yudhistira et al., 2018). Buah nangka memiliki aroma khas yang kuat. Nangka memiliki aroma yang menarik karena mengandung komponen-komponen volatile (Azizah et al., 2013).

Velva dikatakan baik jika memiliki tekstur yang halus dan waktu pelelehan yang lama, sehingga perlu ditambahkan suatu bahan penstabil guna menghasilkan produk velva yang bermutu baik. Bahan penstabil berperan dalam menghasilkan tekstur lembut, membentuk kristal es yang halus, dan menghasilkan daya tahan yang baik terhadap proses pelelehan dengan menyerap dan menahan sejumlah air yang terikat (Soad et al., 2014). Yudhistira et al. (2018) telah melakukan penelitian mengenai velva nangka dengan perlakuan bahan penstabil menggunakan kombinasi CMC dan GA. Namun, CMC yang banyak digunakan dalam proses pengolahan pangan dapat menimbulkan berbagai macam efek samping yang berbahaya. Konsumsi CMC dalam jangka panjang jika tidak digunakan sesuai dosis yang diijinkan akan menyebabkan penyakit kanker, kerusakan ginjal, dan memiliki efek obat usus (pencahar). Dalam kasus lain, seseorang setelah terpapar CMC mengalami anafilaksis dan peradangan usus (Martino et al., 2017). Oleh karena itu, dalam penelitian ini hanya digunakan GA sebagai penstabil velva nangka supaya dihasilkan produk yang aman dikonsumsi.

GA merupakan salah satu bahan penstabil yang cocok digunakan dalam pembuatan velva nangka karena memiliki sifat salah satunya dapat mengikat flavour. GA dapat berfungsi sebagai pengikat aroma pada produk pangan yang bersifat volatile (Christiana et al., 2015). Pada olahan pangan yang banyak mengandung gula, GA digunakan untuk mendorong pembentukan emulsi lemak yang mantap dan mencegah kristalisasi gula. GA juga lebih stabil dalam larutan asam. Penelitian ini bertujuan untuk mengetahui pengaruh penambahan GA sebagai bahan penstabil terhadap karakteristik fisik (overrun dan waktu pelelehan), total padatan, dan hedonik velva nangka.

\section{METODE PENELITIAN}

Penelitian dilaksanakan dari bulan November hingga Desember 2020 di Program
Studi Teknologi Pangan (Laboratorium Kimia dan Gizi Pangan, Laboratorium Rekayasa Pangan dan Hasil Pertanian) dan Laboratorium Terpadu Universitas Diponegoro.

Bahan yang digunakan dalam penelitian ini yaitu buah nangka yang dibeli dari pasar tradisional di Kota Semarang dan bahan penstabil GA yang dibeli di toko bahan kimia serta bahan tambahan lain yang digunakan dalam formula velva (gula pasir, air, dan asam sitrat). Mixer (HR1530/80, Philips, Indonesia) dan ice cream maker (GEA ICE 1530, German) digunakan sebagai alat utama dalam pembuatan sampel velva.

\section{Pembuatan Velva Nangka}

Pembuatan velva nangka mengacu pada Wulandari et al. (2014) yang telah dimodifikasi. Persiapan ekstrak buah nangka dilakukan dengan pencucian terlebih dahulu kemudian buah dikupas dan diambil daging buahnya. Daging buah di blanching pada suhu $90^{\circ} \mathrm{C}$ selama 5 menit lalu dihaluskan menggunakan blender hingga menjadi bubur buah (puree). Rasio puree nangka dengan air $2: 1 \quad(\mathrm{~m} / \mathrm{v})$ dengan ditambahkan sukrosa sebanyak $15 \%$, dan asam sitrat $0,1 \%$ dari total adonan. Adonan dasar velva dibagi menjadi 5 adonan kecil yang masing masing diberi bahan penstabil GA dengan variasi konsentrasi 0; 0,$25 ; 0,5 ; 0,75$; dan $1 \%$ dari total adonan. Komposisi bahan adonan velva nangka dapat dilihat secara lengkap pada tabel 1 . Selanjutnya adonan diaduk menggunakan mixer selama 15 menit di dalam wadah. Adonan yang sudah tercampur rata didinginkan/aging pada suhu 5-6 ${ }^{\circ} \mathrm{C}$ selama 24 jam. Setelah didinginkan, velva dimasukkan ke dalam ice cream maker selama kurang lebih 30 menit. Setelah itu dilakukan pembekuan dalam freezer selama 24 jam dengan suhu sekitar $-20^{\circ} \mathrm{C}$.

\section{Uji Karakteristik Fisik Velva Nangka}

Uji karakteristik fisik pada velva nangka dengan penambahan GA sebagai penstabil meliputi overrun dan waktu pelelehan. Pengujian overrun dilakukan dengan cara adonan gelato sebelum proses aging dimasukkan dalam gelas ukur hingga volumenya mencapai $100 \mathrm{ml}$ lalu ditimbang beratnya. Kemudian dilanjutkan dengan penimbangan gelato yang sudah mengalami proses pengocokan dan pembekuan. Nilai overrun dihitung dengan selisih berat adonan 
gelato dengan berat gelato dibagi berat adonan gelato dikali 100\% (Aulia et al., 2019). Resistensi pelelehan diukur dengan menimbang sampel velva sebanyak 5 gram ke dalam wadah lalu dibekukan dalam freezer selama 24 jam. Setelah pembekuan selesai, sampel diletakkan pada suhu ruang dan dilakukan penghitungan lama waktu sampel velva hingga meleleh sempurna (Susilawati et al., 2014).

Tabel 1. Bahan Adonan Velva Nangka

\begin{tabular}{lccccc}
\hline \multirow{2}{*}{ Bahan } & \multicolumn{5}{c}{$*$ Penambahan GA(\%) } \\
\cline { 2 - 6 } & 0 & 0,25 & 0,5 & 0,75 & 1 \\
\hline Nangka (gr) & 400 & 400 & 400 & 400 & 400 \\
Air (ml) & 200 & 200 & 200 & 200 & 200 \\
Gula (gr) & 40 & 40 & 40 & 40 & 40 \\
Asam sitrat (gr) & 0,4 & 0,4 & 0,4 & 0,4 & 0,4 \\
GA(gr) & 0 & 1 & 2 & 3 & 4
\end{tabular}

*Persentasi penambahan GA adalah terhadap total adonan velva.

\section{Uji Total Padatan Velva Nangka}

Penentuan total padatan dilakukan dengan menghitung kadar air velva terlebih dahulu (Kavaz, 2015). Pertama tama cawan porselin dibersihkan dan dikeringkan dalam oven dengan suhu $105^{\circ}-110^{\circ} \mathrm{C}$ selama 1 jam. Setelah itu didinginkan dalam desikator selama 15 menit dan ditimbang beratnya. Sampel velva nangka diletakkan dalam cawan porselin lalu ditimbang beratnya. Sampel dalam cawan porselin kemudian dikeringkan dalam oven dengan suhu $105^{\circ}-110^{\circ} \mathrm{C}$ selama 24 jam kemudian didinginkan dalam desikator selama 15 menit dan ditimbang beratnya. Penimbangan ini diulang hingga diperoleh berat yang konstan. Kadar air dihitung dengan membagi selisih berat awal dan akhir sampel (setelah dikeringkan) dengan berat awal sampel lalu di kalikan $100 \%$. Total padatan diperoleh dengan mengurangi angka 100\% dengan persentasi kadar air hasil pengujian.

\section{Uji Hedonik}

Uji hedonik mengacu pada Haryanti et al. (2015). Atribut sensori yang diuji meliputi rasa, tekstur, aroma dan overall kesukaan. Pengujian dilakukan oleh panelis semi terlatih sebanyak 25 panelis. Pengujian dilakukan dengan cara panelis mencicipi dan memberi penilaian terhadap tingkat kesukaan sampel dengan mengisi formulir penilaian yang telah dibagikan. Skala skor yang digunakan adalah $1=$ tidak suka; $2=$ =sedikit suka; $3=$ cukup suka; $4=$ suka.

\section{Analisis Data}

Analisis data hasil pengujian sifat fisik dan kimia diuji secara parametrik menggunakan uji ANOVA (Analysis of Variance) dengan taraf signifikansi 5\% untuk mengetahui pengaruh dari perlakuan. Apabila terdapat pengaruh nyata maka dilakukan uji lanjutan menggunakan Duncan Multiple Range Test (DMRT). Analisis sifat hedonik diuji secara non parametrik yaitu menggunakan uji Kruskal-Wallis dengan taraf signifikansi 5\% untuk mengetahui adakah pengaruh signifikan antar variabel. Apabila terdapat pengaruh signifikan maka dilanjutkan uji Mann-Whitney. Analisis data dihitung dengan bantuan program SPSS 26.0 for Windows.

\section{HASIL DAN PEMBAHASAN}

\section{Karakteristik Fisik Velva Nangka}

Karakteristik fisik velva nangka dalam kajian ini ditunjukkan melalui 2 parameter yaitu overrun dan resistensi pelelehan. Overrun merupakan pengembangan volume menunjukkan banyak sedikitnya udara yang terperangkap dalam velva karena proses agitasi. Penambahan GAsebagai bahan penstabil secara signifikan mempengaruhi nilai overrun velva nangka (Tabel 2). GA sebanyak 2,25-0,75\% dalam adonan, tidak menghasilkan velva nangka dengan overrun yang berbeda secara signifikan. Penggunakan GA sebagai penstabil sebanyak $1 \%$ mampu menghasilkan velva nangka dengan overrun yang paling kecil $(\mathrm{p}<0,05)$. 
GA merupakan polimer dengan kandungan protein $5 \%$ yang berpengaruh pada sifat emulsifikasi (Rakasiwi et al., 2014). Pada proporsi yang sangat kecil dalam adonan dimana pada kajian ini adalah di bawah $1 \%$, kemampuan GA sebagai agen pengemulsi tidak begitu kuat. Hal ini disebabkan karena sifat khas dari GA yang cenderung hidrofobik dimana total padatan relatif tinggi namun viskositas cukup rendah (Praseptiangga et al., 2016). Suatu campuran baru akan menunjukkan viskositas yang nyata ketika ditambahkan GA sebanyak 10\% (Indhuja et al., 2013). Makin banyak proporsi GA yang ditambahkan maka viskositas atau kekentalan adonan velva nangka akan semakin meningkat. Viskositas yang tinggi menyebabkan mobilitas molekul air terbatas sehingga ruang antar partikel dalam adonan semakin sempit dan akhirnya udara yang masuk dalam adonan selama agitasi makin sedikit yang berakibat pada makin rendahnya nilai overrun (Andari et al., 2015). Fenomena tersebut tampak pada kajian ini dimana pada penambahkan GA yang terbanyak yaitu $1 \%$ menghasilkan velva nangka dengan overrun yang paling rendah (Tabel 2).

Jika dibandingkan dengan frozen dessert lain seperti es krim dan gelato, overrun velva nangka pada kajian ini tampak jauh lebih rendah. Hal ini disebabkan karena komposisi dasar velva yang tidak menyertakan bahan lemak dan fat mimetics seperti krim susu, susu, dan bahan pengental lain yang berbasis karbohidrat atau pati (Tabel 1). Fat mimetics merupakan senyawa yang sangat berkontribusi pada sifat kekentalan adonan sehingga dapat memberikan sensasi seolah olah ada cita rasa lemak pada produk ketika dimakan. Fat mimetics tersebut dikategorikan sebagai bahan yang berbasis karbohidrat, pati, dan atau protein (Sadowska-Rociek \& Cieślik, 2019). Penelitian sebelumnya tentang pembuatan velva nangka dengan penstabil kombinasi CMC dan GAjuga menunjukkan nilai overrun yang masih dibawah es krim yaitu berkisar antara 16-25\% (Yudhistira et al., 2018).

Lebih lanjut penambahan GAsebagai penstabil juga membawa pengaruh yang signifikan pada resistensi pelelehan velva nangka (Tabel 2). Resistensi pelelehan adalah waktu yang diperlukan oleh frozen dessert untuk mempertahankan bentuk dan teksturnya yang sempurna pada suhu ruang (Pratiiwi et al., 2017). Penambahan GA lebih dari 0,25\% menghasilkan velva nangka dengan resistensi pelelehan yang makin tinggi $(\mathrm{p}<0,05)$ dimana velva tersebut membutuhkan waktu yang lebih lama untuk mencair pada suhu ruang. Proporsi GA0,5 hingga $1 \%$ dalam adonan ternyata masih menampakkan resistensi pelehan yang relatif sama pada velva nangka yang dihasilkan. GA pada proporsi tertentu mampu menyerap air dan mempertahankan fungsi pengikatan air dalam kondisi dingin sehingga proses pelelehan semakin lama dan laju pelelehannya rendah (Yudhistira et al., 2018) Velva nangka dalam kajian ini memiliki resistensi pelelehan yang relatif jauh lebih tinggi (18-23 menit) dari frozen dessert umumnya misalnya es krim yang hanya 10-15 menit (Sistanto et al., 2018). Hal ini disebabkan oleh faktor komposisi velva yang kaya serat sebagai kontribusi dari buah nangka sebagai bahan utamanya (Tabel 1). Penelitian tentang velva nangka dengan kombinasi bahan penstabil CMC dan GA juga menunjukkan kisaran resistensi pelelehan yang lebih lama (21-28 menit) dari es krim (Yudhistira et al., 2018).

Tabel 2. Karakteristik Fisik Velva Nangka

\begin{tabular}{lccccc}
\hline \multirow{2}{*}{ Parameter } & \multicolumn{5}{c}{ Penambahan GA (\%) } \\
\cline { 2 - 6 } & 0 & 0,25 & 0,5 & 0,75 & 1 \\
\hline Overrun & $19,02 \pm 0,34^{\mathrm{c}}$ & $18,45 \pm 0,34^{\mathrm{b}}$ & $18,26 \pm 0,32^{\mathrm{b}}$ & $17,86 \pm 0,44^{\mathrm{b}}$ & $16,93 \pm 0,41^{\mathrm{a}}$ \\
Resistensi Pelelehan & $18,21 \pm 0,80^{\mathrm{a}}$ & $19,70 \pm 0,80^{\mathrm{a}}$ & $22,10 \pm 1,60^{\mathrm{b}}$ & $22,64 \pm 1,23^{\mathrm{b}}$ & $23,87 \pm 1,24^{\mathrm{b}}$ \\
\hline
\end{tabular}

Data ditampilkan sebagai mean \pm standar deviasi. Superskrip huruf kecil yang berbeda pada baris yang sama menunjukan adanya perbedaan nyata $(\mathrm{p}<0,05)$.

\section{Total Padatan Velva Nangka}

Penggunana GA memberikan pengaruh yang signifikan terhadap total padatan velva nangka. Penambahan GA0,75-1\% pada adonan menghasilkan velva nangka dengan total padatan yang lebih tinggi secara signifikan (Gambar 1). GA merupakan penstabil yang bersifat hidrokoloid sehingga dapat menyerap air dengan baik (Goff \& Guo, 2018). Semakin banyak GA ditambahkan 
maka semakin banyak partikel air yang terikat sehingga menurunkan kadar air velva. Pengurangan kadar air dapat menyebabkan peningkatan konsentrasi padatan pada bahan pangan (Septiani et al., 2013). Penelitian terdahulu juga menunjukkan bahwa velva nangka dengan total padatan tertinggi dihasilkan oleh adonan yang diberi bahan penstabil GA dengan rasio yang lebih tinggi daripada penstabil CMC (Yudhistira et al., 2018).

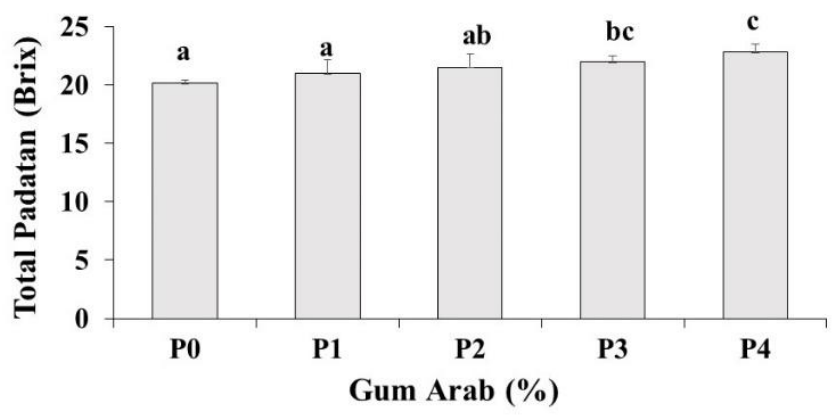

Gambar 1. Total padatan velva nangka dengan penambahan GA0\% $\left(\mathrm{P}_{0}\right) ; 0,25 \%(\mathrm{P} 1) ; 0,5 \%\left(\mathrm{P}_{2}\right) ; 0,75 \%\left(\mathrm{P}_{3}\right)$, dan $1 \%\left(\mathrm{P}_{4}\right)$. Superskrip huruf yang berbeda pada grafik batang menunjukan adanya perbedaan nyata $(\mathrm{p}<0,05)$

Tabel 3. Hedonik Velva Nangka

\begin{tabular}{llllll}
\hline \hline Atribut Sensori & \multicolumn{5}{c}{ Penambahan GA (\%) } \\
\cline { 2 - 6 } & \multicolumn{1}{c}{0} & \multicolumn{1}{c}{0,25} & 0,5 & \multicolumn{1}{c}{0,75} & \multicolumn{1}{c}{1} \\
\hline Rasa & $2,48 \pm 0,82$ & $2,60 \pm 0,86$ & $2,80 \pm 0,64$ & $2,84 \pm 0,80$ & $3,04 \pm 0,68$ \\
Tekstur & $2,32 \pm 0,63^{\mathrm{a}}$ & $2,40 \pm 0,76^{\mathrm{a}}$ & $2,68 \pm 0,69^{\mathrm{a}}$ & $2,84 \pm 0,90^{\mathrm{ab}}$ & $3,08 \pm 0,76^{\mathrm{b}}$ \\
Aroma & $2,52 \pm 0,71$ & $2,68 \pm 0,69$ & $2,88 \pm 0,67$ & $2,80 \pm 0,76$ & $3,00 \pm 0,76$ \\
Overall & $2,56 \pm 0,58^{\mathrm{a}}$ & $2,60 \pm 0,71^{\mathrm{a}}$ & $2,92 \pm 0,57^{\mathrm{ab}}$ & $3,04 \pm 0,89^{\mathrm{b}}$ & $3,12 \pm 0,67^{\mathrm{b}}$ \\
\hline
\end{tabular}

Data ditampilkan sebagai mean \pm standar deviasi. Superskrip huruf kecil yang berbeda pada baris yang sama menunjukan adanya perbedaan nyata $(\mathrm{p}<0,05)$. Skala hedonik $1-4$ berturut-turut menyatakan (1) tidak suka, (2) sedikit suka, (3) cukup suka, dan (4) suka.

\section{.Hedonik Velva Nangka}

Pengujian hedonik (kesukaan) perlu dilakukan untuk melihat tingkat penerimaan konsumen terhadap suatu produk. Dalam kajian ini atribut hedonik velva nangka yang diuji antara lain rasa, tekstur, dan aroma. Penambahan GA sebagai penstabil pada produksi velva nangka secara signifikan hanya mempengaruhi tingkat kesukaan terutama pada tekstur dimana 1\% GA dalam adonan menghasilkan tekstur velva yang lebih disukai karena terasa lebih lembut ketika dikonsumsi (Tabel 3). GA merupakan jenis hidrokoloid yang memiliki kemampuan yang baik dalam mengikat air sehingga menghindari terbentuknya kristal es kasar yang terlalu banyak (Rini et al., 2012; Lestari et al., 2017). Tekstur yang ideal bagi velva adalah tekstur yang halus dan ukuran partikel padatan sangat kecil sehingga tidak terdeteksi dalam mulut. Secara umum penambahan GA lebih dari 0,75 $\%$ mampu menghasilkan produk velva nangka yang lebih disukai daripada tanpa GA ataupun sedikit gum arab. Sementara itu penambahan GA tidak mempengaruhi kesukaan terhadap rasa dan aroma velva nangka dimana produk tetap melikisi rasa dan aroma buah nangka sebagai bahan baku velva (Tabel 3). Faktor utama yang mempengaruhi daya terima terhadap produk pangan adalah rangsangan citarasa yang ditimbulkan (Salimah et al., 2015). GA tidak mempengaruhi rasa pada produk pangan karena merupakan zat yang tidak berasa dan berbau (Widiantoko \& Yunianta, 2014).

Velva nangka memiliki aroma khas nangka yang kuat. Aroma khas buah nangka berasal dari senyawa etil butirat yang terdapat dalam daging buah. Aroma merupakan parameter untuk menentukan tingkat penerimaan konsumen dengan cepat dan dianggap memberikan penilaian antara suka atau tidak (Risti \& Herawati, 2017). 


\section{KESIMPULAN}

Penambahan penstabil Gum Arab (GA) $1 \%$ dalam adonan menghasilkan velva nangka dengan overrun yang rendah, resistensi pelelehan dan total padatan yang lebih tinggi dengan tekstur yang lebih lembut sehingga menjadi produk yang cukup disukai. Pemanfaatan GA sebagai penstabil diharapkan dapat meningkatkan diversifikasi pengolahan nangka sebagai frozen dessert yang berkualitas.

\section{DAFTAR PUSTAKA}

Andari, E.S., Wulandari, E. \& Robin, D.M.C. 2015. Efek larutan kopi robusta terhadap kekuatan tekan resin komposit nanofiller. Stomatognatic-Jurnal Kedokteran Gigi, 11(1): 6-11.

Ariska, S.B. \& Utomo, D. 2020. Kualitas minuman serbuk instan sereh (Cymbopogon citratus) dengan metode foam mat drying. Teknologi Pangan: Media Informasi dan Komunikasi Ilmiah Teknologi Pertanian, 11(1):4251.

Aulia, S., Rizqiati, H., \& Nurwantoro, N. 2019. Pengaruh Substitusi Kefir Terhadap Sifat Fisik, Total Khamir dan Hedonik Es Krim. Jurnal Teknologi Pangan, 3(2):192-198.

Azizah, N., Pramono, Y.B. \& Abduh, S.B.M. 2013. Sifat fisik, organoleptik, dan kesukaan yogurt drink dengan penambahan ekstrak buah nangka. Jurnal Aplikasi Teknologi Pangan, 2(3):148-151.

Christiana, M.A., Radiati, L.E. \& Purwadi. 2015. Pengaruh GApada minuman madu sari apel ditinjau dari mutu organoleptik, warna, $\mathrm{pH}$, viskositas, dan kekeruhan. Ilmu dan Teknologi Hasil Ternak, 10(2):46-53.

Farikha, I.N., Anam, C. \& Widowati, E. 2013. Pengaruh jenis dan konsentrasi bahan penstabil alami terhadap karakteristik fisikokimia sari buah naga merah (Hylocereus polyrhizus) selama penyimpanan. Teknosains Pangan, 2(1):30-38.

Goff, H.D. \& Guo, Q. 2019. The role of hydrocolloids in the development of food structure. In Handbook of Food Structure Development, pp. 1-28.
Hendrianto, E. \& Rukmi, W.D. 2015. Pengaruh penambahan beras kencur pada es krim sari tempe terhadap kualitas fisik dan kimia. Jurnal Pangan dan Agroindustri, 3(2):353-361.

Indhuja, A., Suganthi, K.S., Manikandan, S., \& Rajan, K.S. 2013. Viscosity and thermal conductivity of dispersions of gum arabic capped MWCNT in water: influence of MWCNT concentration and temperature. Journal of the Taiwan Institute of Chemical Engineers, 44(3): 474-479.

Istiqomah, K., Praptiningsih, Y. \& Windrati, W.S. 2018. Karakterisasi es krim edamame dengan variasi jenis dan jumlah penstabil. Jurnal Agroteknologi, 11(2):139-147.

Kavaz Yuksel, A. 2015. The Effects of Blackthorn ( $P$ runus Spinosa L.) Addition on Certain Quality Characteristics of Ice Cream. Journal of Food Quality, 38(6):413-421.

Lestari, S.D., Ayu, D.F. \& Rahmayuni. 2017. Pengaruh kombinasi $\mathrm{cmc}$ dan GAterhadap mutu sensori velva ubi jalar ungu. Jurnal Online Mahasiswa Fakultas Pertanian, 4(2):1-10.

Maria, D.N. \& Zubaidah, E. 2014. Pembuatan velva jambu biji merah probiotik (Lactobacillus acidophilus) kajian persentase penambahan sukrosa dan CMC. Jurnal Pangan dan Agroindustri, 2(4):18-28.

Martino, J.V., Limbergen, J.V. \& Cahill, L.E. 2017. The role of carrageenan and carboxymethylcellulose in the development of intestinal inflammation. Frontiers in Pediatrics, 5(96): $1-7$.

Mulyani, D.R., Dewi, E.N. \& Kurniasih, R.A. 2017. Karakteristik es krim dengan penambahan alginat sebagai penstabil. Jurnal Pengolahan dan Bioteknologi Hasil Perikanan, 6(3):3642.

Muzaifa, M. 2018. Perubahan komponen kimia belimbing wuluh (Averrhoa bilimbi L.) Selama pembuatan asam sunti. Jurnal Teknologi Pertanian Andalas, 22(1):37-43. 
Praseptiangga, D., Aviany, T.P. \& Parnanto, N.H.R. 2016. Pengaruh penambahan gum arab terhadap karakteristik fisikokimia dan sensoris fruit leather nangka (Artocarpus heterophyllus). Jurnal Teknologi Hasil Pertanian, 9(1): 71-83.

Prasetyowati, D.A., Widowati, E. \& Nursiwi, A. 2014. Pengaruh penambahan GAterhadap karakteristik fisikokimia dan sensoris fruit leather nanas (Ananas comosus L. Merr.) dan wortel (Daucus carota). Teknologi Pertanian, 15(2): 139-148.

Pratiiwi, K.I., Zaini, M.A. \& Nazaruddin, N. 2017. Pengaruh konsentrasi gel buah okra (Abelmoschus esculentus L.) terhadap mutu es krim campuran susu sapi dan susu kedelai. Jurnal Pro Food, 2(2):131-139.

Rakasiwi, P., Iftitah, E.D. \& Utomo, E.P. 2014. Pengaruh Perbandingan Bahan Pelapis Maltodekstrin Dan Gum Arab Dalam Mikrokapsul Berbahan Inti Sitronelal. Jurnal Ilmu Kimia Universitas Brawijaya, 2(1):295-300.

Reineccius, G.A. 2002. Carbohydrat for flavour encapsulation. Food Technology March, 45(3):144-146.

Rini, A.K., Ishartani, D. \& Basito, B. 2012. Pengaruh kombinasi bahan penstabil cmc dan GAterhadap mutu velva wortel (Daucus carota L.) varietas selo dan varietas Tawangmangu. Jurnal Teknosains Pangan, 1(1):86-94.

Risti, A.P. \& Herawati, N. 2017. Pembuatan Fruit Leather dari Campuran Buah Sirsak (Annoma muricata L.) dan Buah Melon (Cucumis melo L.). Jurnal Online Mahasiswa, 4(2):1-15.

Sadowska-Rociek, A., \& Cieślik, E. 2019. Carbohydrate-based fat mimetics can affect the levels of 3-monochloropropane-1, 2-diol esters and glycidyl esters in shortbread biscuits. Plant Foods for Human Nutrition, 74(2):216222.

Salimah, D.M., Lindriati, T. \& Purnomo, B.H. 2015. Sifat fisik dan kimia puree jambu biji merah (Psidium guajava L.) dengan penambahan GA dan gum xanthan. Agroteknologi, 9(2):145-155.
Santoso, B., Herpandi, H., Pitayati, P.A. \& Pambayun, R. 2013. Pemanfaatan karaginan dan gum arabic sebagai edible film berbasis hidrokoloid. Agritech, 33(2): 140-145.

Satriono, S., Johan, V.S. \& Hamzah, F. 2018. Pemanfaatan tomat dan nanas dalam pembuatan. Teknologi Pangan, 5(1):115.

Septiani, I.N., Basito \& Esti, W. 2013. Pengaruh konsentrasi agar-agar dan karagenan terhadap karakteristik fisik, kimia, dan sensori selai lembaran jambu biji merah (Psidium guajava L.). Jurnal Teknologi Hasil Pertanian, 6(1):27-35.

Sistanto, S., Sulistyowati, E. \& Yuwana, Y. 2017. Pemanfaatan limbah biji durian (Durio zibethinus Murr) sebagai bahan penstabil es krim susu sapi perah. Jurnal Sain Peternakan Indonesia, 12(1):9-23.

Soad, H.T., Mehriz, A.M. \& Hanafy, M.A. 2014. Quality characteristics of ice milk prepared with combined stabilizers and emulsifiers blends. International Food Research Journal, 21(4):1609-1613.

Susilawati, S., Nurainy, F. \& Nugraha, A.W. 2014. Pengaruh penambahan ubi jalar ungu terhadap sifat organoleptik es krim susu kambing peranakan etawa [The Influence of Purple Sweet Potato Increment og Organoleptic Characteristic of Goat Milk Ice Cream of Etawa Generation]. Jurnal Teknologi \& Industri Hasil Pertanian, 19(3): 243256.

Sylvi, D., Novelina, N. \& Kurniat, A. 2020. Pengaruh pencampuran bengkuang (Pachyrhizus erosus L.) dengan terung belanda (Cyphomandra betacea Sendtn) terhadap karakteristik velva dihasilkan. Litbang Industri, 10(1):2331.

Tantono, E., Effendi, R. \& Hamzah, F.H. 2017. Variasi rasio bahan penstabil $\mathrm{cmc}$ (carboxy methyl cellulose) dan GAterhadap mutu velva alpukat (Parsea americana Mill.). Online Mahasiswa Faperta, 4(2):1-15.

Widiantoko, R.K. \& Yunianta. 2014. Pembuatan es krim tempe-jahe (kajian proporsi bahan dan penstabil terhadap sifat fisik, kimia, dan organoleptik). Jurnal Pangan dan Agroindustri, 2(1): 54- 66. 
Widyaningtyas, M \& Susanto, W.H. 2015. Pengaruh konsentrasi hidrokoloid (carboxy methyl cellulose, xanthan gum dan karagenan) terhadap karakteristik mie kering berbasis ubi jalar varietas ase kuning. Pangan dan Agroindustri, 3(2):417-423.

Wulandari, B., Ishartani, D. \& Affandi, D.R. 2014. Penggunaan pemanis rendah kalori pada pembuatan velva ubi jalar oranye (Ipomoea batatas L.). J. Teknosains Pangan, 3(3):12-21.
Yudhistira, B., Riyadi, N.H., Pangestika, A.D. \& Pertiwi, S.R. 2018. Effect of CMC and arabic gum in the manufacture of jackfruit velva (Artocarpus heterophyllus). IOP Conf. Series: Earth and Environmental Science 142.

Yuliwaty, S.T. \& Susanto, W.H. 2014. Pengaruh lama pengeringan dan konsentrasi maltodekstrin terhadap karakteristik fisik kimia dan organoleptik minuman instan daun mengkudu (Morinda citrifolia L.). Pangan dan Agroindustri, 3(1):41-52. 